\title{
Joan Salvador and James Petiver: the last years (1715-1718) of their scientific correspondence
}

\author{
JOSEP M. CAMARASA ${ }^{\mathrm{A}}$ and NEUS IBÁÑEZ ${ }^{\mathrm{B}}$ \\ A Grup de Treball d'Història de la Ciència, Institut d'Estudis Catalans, Carme, 47, E-08001 Barcelona, Catalonia, \\ Spain (e-mail: josepm.camarasa@marimurtra.cat). \\ ${ }^{\mathrm{B}}$ Institut Botànic de Barcelona (IBB-CSIC-ICUB), Passeig del Migdia s/n, E-08038 Barcelona, Catalonia, Spain \\ (e-mail: nibanez@ibb.csic.es).
}

\begin{abstract}
At the time of the war of the Spanish Succession (1705-1714), Joan Salvador and James Petiver, two apothecaries with an impassioned interest in understanding nature, began a long and fruitful correspondence that would only come to an end with Petiver's death in 1718. A previous paper sets out and discusses these two naturalists' correspondence (which is quite exceptionally complete) during the wartime period between the end of 1706 and the fall of Barcelona on 11 September 1714. This paper completes the review and discussion of their correspondence up until the death of Petiver in 1718.
\end{abstract}

KEY WORDS: Catalonia - collections - history of science.

RESUM: En mig de la Guerra de Successió d'Espanya (1705-1714), Joan Salvador i James Petiver, dos apotecaris curiosos $\mathrm{i}$ apassionats pel coneixement de la natura havien iniciat una llarga i fructífera correspondence, que havia de perdurar fins a la mort de Petiver el 1718. En un article anterior s'havia recollit i comentat la correspondence (excepcionalment completa) intercanviada entre aquests dos naturalistes durant el període de guerra que va de finals del 1706 fins a la caiguda de Barcelona l'11 de Setembre de 1714. En aquest es completa l'estudi de la correspondencia entre els dos naturalistas fins a la mort de Petiver.

KEY WORDS: Catalunya - col-leccions - història de la ciència.

\section{INTRODUCTION}

The Catalan naturalist and apothecary Joan Salvador i Riera (1683-1726) initiated a lengthy correspondence with the English naturalist James Petiver (c. 1663-1718) in December 1706 (Camarasa and Ibáñez 2007: 142). The early part of their exchange, covering the eight and a half year from the first of Joan Salvador's letters until Petiver's letter of 25 April 1715, in which he joyfully announced that he has learnt of his correspondent's survival following the fall of the city of Barcelona on 11 September 1714, contrary to what he had previously been led to believe, has already been documented (Camarasa and Ibáñez 2007). This paper covers the subsequent correspondence, which ceased on Petiver's death. Transcripts of the letters are provided (together with other documents) in the original language (French in Joan Salvador's letters, English in James Petiver's, and Latin in an occasional letter or document enclosed with the correspondence), and they are set in their historical, social and scientific context. An evaluation is also made of the testimony the letters give about the scientific activities of both correspondents and their respective networks of scientific correspondence. ${ }^{1}$ 


\section{THE RESUMPTION OF CORRESPONDENCE}

The reply by Petiver ${ }^{2}$ to Joan Salvador's letter, in which he disclosed that he had survived the siege and final storming of Barcelona by the forces of Philip V, saw the start of a particularly productive stage in terms of the exchange of letters, natural history materials and publications between them. On the one hand, the end of the war saw the correspondence between the two become freer and more diversified. In particular, for both Salvador and Petiver, direct communication with French correspondents became possible again after a break of almost ten years. For Salvador this was of particular importance in that he was able to re-establish contact with the roots of his scientific training in Montpellier and Paris and with his esteemed teachers and fellow students. On the other hand, Joan Salvador was no longer the budding naturalist seeking to join networks of the natural history establishment. Throughout the war, especially during the years when the court of Charles III of Habsburg was established in Barcelona, he had crossed paths, in the gatherings in the back room of his father's establishment and the salons of the court, with the cream of European physicians, surgeons and apothecaries as well as with other high ranking individuals who were all equally interesting to him as far as natural history was concerned. In 1715, Salvador was already treating Petiver as his equal, and in London he likewise socialized with Hans Sloane, John Lecaan, Georges Hay and Isaac Rand. It was the same in Leiden with Hermann Boerhaave, in Paris with Sebastien Vaillant and Antoine de Jussieu, and in Montpellier with Pierre Magnol (who unfortunately died that same year, 1715). His relations with the court had become more distant however. The erstwhile courtiers of Charles III in Barcelona had either died in the war or had followed their sovereign, who was now Emperor Charles VI, to Vienna. The court in Madrid was also a long way away, and not just geographically; the Catalans were being treated as a conquered people and were distrusted by the Spanish authorities. Nevertheless, Petiver, from his first letter after the defeat, did his best to help the Catalan Salvador establish ties with the court of Philip V and gave him advice on how to do so.

As pointed out by us (Camarasa and Ibáñez 2007: 159), there are some notable peculiarities about this first letter from Petiver after the war, aside from his quite natural expressions of joy at the news that his friend who he thought had died was in fact in good health and had written to him. First, the letter was on the back of a sheet with illustrations of 16 different seaweeds copied from Barrelier's Icones $^{3}$ (Jussieu 1714), the printed title being "Fuci, Spongiae, Pennae \& Musci maris MEDITERRANEA": a subtitle, handwritten by Petiver, read "Levant Sea-Weeds TAB. I", and the names of the various "sea-weeds" illustrated, according to Barrelier's nomenclature

London April the $25^{\text {th }} 1715$

My Very Worthy Friend

$\mathrm{S}^{\mathrm{r}}$ It was [with] no small Joy when I rece'd $y^{\mathrm{r}}$ signed Decemb. $6^{\text {th }} 1714$ with $\mathrm{yo}^{\mathrm{r}}$ own hand (which I was formerly well acquainted with) hearing you have been dead, reading that one of $y^{r}$ name was killed upon the Breach, I hope now [illeg.] shall have a more frequent Correspondence together $\&$ be assured you shall suddenly receive [illeg.] Plants, Shells, \&c some of which I am sure you never saw before. I write this to save postage on Tables of Plantae Submarinae Mediterranei wich I have taken out of Barrelieri Icons. [I] hope you will find most of them on your Shoars which I should be glad to see I have allso figured all the grasses which he had observed $a b^{t}$ Rome, which are $a b^{t} 50$ these I will send you by my next, as allso my Pterigraphia Americana containing the compleat figures of near 200 Rare American Ferns taken mostly from Plumier's Hist. des Fouguieres ${ }^{4}$ to which I have added divers Sea productions \& some Animalls, I am now graveing 50 Medicinall Plants from Peru \& Chili Coppied from Feuillé Designs, I must desire to know what Conveniences you have to 
Table 1. Chronological* table of correspondence transcribed

The correspondence before 11 September of 1714 was published in Camarasa and Ibáñez (2007)

Sender
Joan Salvador
John Petiver
Joan Salvador
John Petiver
Joan Salvador
John Lecaan
John Lecaan
John Petiver
John Petiver
Joan Salvador
John Petiver
John Lecaan
John Petiver
Joan Salvador
Joan Salvador
Joan Salvador
Joan Salvador
Joan Salvador
Joan Salvador
Joan Salvador
Joan Salvador
John Petiver
Joan Salvador
Joan Salvador
Joan Salvador
John Petiver
John Petiver
Joan Salvador
Joan Salvador
John Petiver
Joan Salvador
Joan Salvador
Joan Salvador
John Petiver
Joan Salvador
Joan Salvador
John Petiver
Joan Salvador
Joan Salvador
John Petiver
Joan Salvador
John Petiver
John Petiver
Joan Salvador
Joan Salvador
Joan Salvador
John Petiver

Date of shipping

24 December 1706

21 April 1708

22 September 1708

3 October 1708

8 November 1708

10 February 1709

17 February 1708/09

29 September 1709

16 January 1710

10 February $1709 / 10$

20 April 1710

5 September 1710

12 February 1711

30 July 1711

20 September 1711

20 November 1711

12 December 1711

10 January 1712

26 January 1712

2 February 1712

15 July 1712

15 April 1712

22 August 1712

22 August 1712

14 October 1712

10 August 1713

between 12 September and 6 December 1714

6 December 1714

25 April 1715

8 September 1715

10 September 1715

10 September 1715

15 November 1715

4 January 1716

6 April 1716

29 May 1716

2 August 1716

9 August 1716

September 1716

26 February 1717

15 March 1716/17

23 April 1717

August 1717

14 October 1717

13 November 1717

25 November 1717

5 December 1717

18 January 1717/18
Recipient

John Petiver

Joan Salvador

John Petiver

John Lecaan

John Petiver

John Petiver

John Petiver

John Lecaan

John Lecaan

John Petiver

John Lecaan

John Petiver

Joan Salvador

John Petiver

John Petiver

John Lecaan

John Lecaan

John Petiver

John Petiver

John Petiver

John Petiver

Joan Salvador

John Petiver

John Petiver

Hans Sloane

Joan Salvador

Joan Salvador

John Lecaan

John Petiver

Joan Salvador

John Petiver

John Petiver

Hans Sloane

Joan Salvador

John Petiver

John Petiver

Joan Salvador

John Petiver

John Petiver

Joan Salvador

John Petiver

Joan Salvador

James Campbell

John Petiver

Hans Sloane

Hans Sloane

Joan Salvador

\author{
Date of reception \\ 16 June 1707 \\ end of August 1708 \\ 5 January 1708/09 \\ 11 February 1708/09 \\ 11 February 1708/09
}

26 February 1709/10

7 June 1710

from Tarragona

November 1710

31 May 1711

6 November 1711

from Mahon

30 April 1713

after 11 September 1714

26 September 1715

21 March 1715/16

3 February 1715/16

24 April 1716

8 August 1716

23 August 1716

23 August 1716 (?)

25 June 1717

from Lisbon

November 1717

not found

\footnotetext{
* The calendars used in England and Catalonia at the time of this correspondence were different. In Catalonia, the Gregorian calendar came into use in 1582, whereas in England the Julian calendar remained until 1752.

In this table, we have retained the dates as they were written on the transcribed documents. Eleven days need to be added to the sending or delivery dates of James Petiver's letters in order to ascertain the corresponding date in the Gregorian calendar. Moreover, in England at this time the year did not begin on the first day of January, but rather on 25 March (Old Style - OS). For this reason, some dates within the first three months of the year according to the current calendar but to the previous year according to the old one have a dual year, as was the practice in England at the time of the correspondence.
} 
send to Madrid, because with yo ${ }^{\mathrm{r}}$ Collections I shall have an Occasion to send some Things to Mons ${ }^{\mathrm{r}}$ Riquere, the Kings Apothecary, $D^{r}$ Burlett his Premier Physician \& others, from whome I have rece'd some seeds by my Lord Lexington our late Ambassadour \& [illeg.] promised severall other things, I [was] some Time before the Seige of Barcelona with $\mathrm{M}^{\mathrm{r}}$ Romani who told me I might suddenly expect the Mony from you, which I supose the times prevented, nor have I before or since [illeg.] the Mony you mention for $\mathrm{M}^{\mathrm{r}}$ Crower Shallet, the sume I last sent you was 23 pounds, 4 shillings \& 5 pence, which will [illeg.] me into a Condition to goe vigorously on with the rest of Mr Ray ${ }^{\mathrm{s}}$ English Plants, afterwich I intend to figure our Brittish Submarines, Fungi, Mosses, Filices, Gramina, Cyperi \& Junci, I am not a little bigg with the expectations of many curious Plants, Insects \& Fossills you will find in yo $^{\mathrm{r}}$ Travells to the Pyrenees \& Montserrat $\&$ shall make an Ample Return for what of them I shall receive from you $\&$ with yo ${ }^{\text {rs }}$ Leave shall figure all such Things [illeg.] are new or peculiar to these Mountains. I should be glad to know if you have any Correspondence with $\mathrm{D}^{\mathrm{r}}$ Nissole who I hear had printed a Botanicum Avinionense which if you can procure me I will pay the Charge off, I hope now you will have frequent opportunities of sending Collections of Insects, Shells, Fossills \& Plants with their fresh seed or fruit, for which by every shipping, I will make you a Suitable Return who am

Worthy S

Yo $^{r}$ very Affectionate Friend \& Humble Serv ${ }^{t}$

James Petiver

Mons ${ }^{\mathrm{r}}$ Jean Salvadore Apotiquaire \& Botaniste tres celebre A Barcelone avec celerité

The second page had 16 more illustrations of marine organisms from the eastern Mediterranean, - "Musci marini. Corallinae \&c Maris MEDITERRANEI" - annotated by Petiver, "Levant Sea-Mosses \&c. TAB. II", again with the names of "Sea-mosses" according to Barrelier's nomenclature. On the back of this page, there is a desideratum list of 43 Hispanic plants taken from Barrelier's Icones. It is surprising how Petiver was clearly up to date concerning publications like Barrelier's Icones and the first volume of Feuillée's Histoire des plantes medicinales qui sont le plus en usage aux royaumes du Perou et du Chili, both of which were published just one year before (1714) in Paris. He was so up-todate in fact that in 1715 he was already disseminating printed copies with reproductions of some of the engravings in these works.

Nevertheless, the bulk of the letter aimed at helping Joan Salvador find his way into the court, or at least to move in the circles of influential figures such as Claude Burlet and Louis Riqueur. Claude Burlet (1664-1731) had come to Spain with Philip V as the royal physician to the new king. A member of the Academie Royale des Sciences in Paris from 1699, in 1707 he was appointed one of the three "Protomédico de Castilla" and, in 1716, became First Physician to the King and Head of the "Protomedicato". Louis Riqueur (d. 1737) was appointed the first apothecary to the king. In 1713, he planted a herb garden in Migas Calientes, just outside Madrid, which was the origin of the Real Jardín Botánico in Madrid following its donation to the crown and subsequent move to its present-day location in Paseo del Prado. Petiver knew them indirectly through Robert Sutton (1661-1723), Baron Lexington, ambassador-extraordinary and plenipotentiary of Queen Anne in Madrid from 1712 to 1713 . Petiver offered to act as Salvador's intermediary to encourage relations between the "curious" French who had settled in Madrid and the "curious" Catalans from Barcelona, led by Joan Salvador and his father Jaume Salvador.

We do not know why it was difficult for Petiver to communicate with the physician and naturalist from Montpellier, Guillaume Nissole (1647-1734), once peace was restored between France and England. Nevertheless, it was a good idea to rely on Salvador to try and start up correspondence again with him. Both Joan Salvador and his father had gathered plants with Nissole in the outskirts of Montpellier and possibly even further afield. Following the war-time interruption, correspondence was resumed. ${ }^{6}$ In any event, the "Botanicum Avinionense", which Petiver referred to, was not written; Nissole did spend a 
large part of his life trying to produce a work on the flora of the Languedoc region although he never finished it. ${ }^{7}$

\section{JOAN SALVADOR'S REPLY}

Being a Catalan of upright nature, Salvador first sought to pay off his debts to Petiver. The letter bears the date 8 September 1715 and would appear that after several frustrated attempts, a banker's draft endorsed by George Crowe to his brother Mitford enabled him to settle a debt he had run up with Petiver. ${ }^{8}$ Although communications between English and Catalan ports had apparently not returned to normal after the end of the war in Catalonia, some ships were expected set sail for London in the near future and Salvador began to prepare all kinds of curiosities. These were not addressed directly to Petiver, but went to John Lecaan.

\footnotetext{
Sir

After having unsuccessfully tried on several occasions to send you the money that you spent on my behalf, I have just received this banker's draft that Mr. [George] Crowe has given me for his brother Mitford Crowe. It is payable on demand. According to your calculations of the amount for the books you have sent, the total comes to 23 pounds, 4 shillings and 5 pence. I apologize for Mr. Mitford Crowe's delay, they will inform you at Mr. Mestins' house, he lives just opposite the Royal Exchange in Cornhill. I trust you will be paid on presentation of the draft, and I ask you to inform me once you have been paid.

I have a small box almost ready to send you at the first opportunity. Mr. Crowe has told me that some ships are leaving in October and he will ensure that it is shipped then. I will address it to Dr. Lecaan. There are seeds, plants, stones \&c. I anxiously await a shipment from you, especially shells, stones and minerals from England. If there is some new book, please send it, and I wholeheartedly look forward.

Sir

Your most humble and obedient servant and friend

Barcelona, 8 September 1715

Joan Salvador, apothecary from Barcelona
}

[Red. Sept. 26. 1715] ${ }^{9}$

This shipment is confirmed by two identical short letters, dated two days later, one addressed to Petiver ${ }^{10}$ and the other to Hans Sloane. ${ }^{11}$

Barcelona, 10 September 1715

Sir

I am sending a small box to you, addressed to doctor Lecaan, with a few shells and stones, a small package with dried plants and another with some seeds. I have not been able to go out and gather plants as I had planned, but in the meantime please accept these few things. Hoping you will be kind enough as to send me some of your rarities and to trust that I am truly,

Sir, your most humble and obedient servant

Joan Salvador, apothec. in Barcelona

Written on the letter sent to Petiver, there are two notes by Petiver. Below the date of the shipment is the date of receipt, 21 March 1716. Thus, whereas the letter reached him in just over a fortnight, the specimens took more than six months to reach London. The other note, at the end, indicated that the consignment was handed over to Lecaan by Pierre Roevans, who has not been identified.

Petiver's next letter ${ }^{12}$ confirmed the arrival of the letter in which Salvador had enclosed the banker's draft for Mitford Crowe. However, he expressed his displeasure at not having received the shells, stones, dried plants and seeds (which would not arrive until the following 
March) and also bemoaned the fact that Salvador had again chosen Lecaan, who lived in the country outside of London, as an intermediary. ${ }^{13}$ This letter was written, like the previous one, on the back of a printed sheet, which comprised the third plate from Gramina Italiana that he had published; the fourth plate was used as the envelope.

My Dear and Hearty friend

I rece'd both yours of September the $8^{\text {th }} \&$ the money you ordered for which I returne you my hearty thanks but the [six pounds] you mention to have ordered to me in $7^{\text {bre }} 1708 \mathrm{I}$ have not yet rece'd and Mr Mitford Crow tells me he was then in the West Indies so that you must acquaint his brother of it's not being paid who will sett it to rights: I do not find by $\mathrm{y}^{\mathrm{r}}$ last letter you have rece'd mine of $25^{\text {th }}$ of April which I sent inclosed to Captn Jones $^{14}$ secretary to Mr Methwyn ${ }^{15}$ at Madrid but I hope by this you have rece'd it which pray let me know, it was on a sheet whereon was 2 Tables of Italian submarines as this is with 2 other of Roman Grasses diver's of wich I hope you will find about Barcellona with other very different from them which I should be glad to see. I have this day comeing out of the profs a Catalogue of Etrurian or Tuscan Plants the Choice of which I have chiefly extracted from that Curious Author Andreas Cesalpino, this with some other Tracts I have lately published, I will take the first Opportunity of sending you with diver's Plants, Shells, \&c. Mr Crowe or Mr Shallet can advise you into whose hands here in London I may put them for you and to them you may allso consign what you have for me, which will be the Easiest, Quickest and safest way, You tell me of some Seeds, Plants, Stones, \&c. which you design to direct to $\mathrm{D}^{\mathrm{r}}$ Lecaan who lives now in the Country but where I cannot learn, so that I fear they will not come to my hands and if they fall into $\mathrm{M}^{\mathrm{r}}$ Rand's ${ }^{16}$ he will keep them \& he has allready a Collection of mine from Holland. So that I desire you will direct to my own hands what you design for me. I desired in my last to knowe what Conveniences and how often you have Opportunities of sending to Madrid which pray let me knowe by the first Post because I have some Books \&c. to send to $\mathrm{M}^{\mathrm{r}}$ Burlett the king's chief Phisitian and Mons ${ }^{\mathrm{r}}$ Riquier the late Queen's Apothecary which [illeg.] thro' your hands may be of no disservies to you at that Court. ${ }^{17} \mathrm{I}$ am sorry to hear by this days mails from Holland and France of the Pest of the Spanish Flotilla in which $\mathrm{D}^{\mathrm{r}}$ Langlade ${ }^{18}$ gave me some hopes I might receive something from Peru, Mexico \&c. A Correspondence from these part would be very acceptable, which I hope you will allso Endeavour to promote as allso to the Phylipine Islands where I have now lost the Curious Father Camelle with whom \& till his Death I had a yearly Corespondence as you may see by the Appendix to Mr Ray's third Volum of Plants the designs of which I have not yet engraved for want of Incouragment and Subscriptions which I have accquainted the Court of Madrid with in hopes of the King's Assistance $\left[\mathrm{T}^{\mathrm{t}}\right]$ being too heavy for my own privat Pockett. [illeg.] part I have allready mostly printed in our Phylosophicall Transactions and $\left[\mathrm{M}^{\mathrm{r}}\right]$ Ray so that the figures are only wanting to illustrate them. But to come nearer home let me accquaint you I hope before Middsummer next to have compleatted my British Herball Viz: the figures of a 1000 herbs and Trees the 50 Tables I have allready published ending [so] the first part of the Tetrapetalae; since which I have finished the second part [\&c]: the Tetrapetalae Anomalae Ray and all the Pentapetalae so that there only remain [illeg.] the leguminosae, Bulbosae Anomalae \& Trees, After which [if] I meet with Incourgm ${ }^{t}$ I shall proceed to the Grasses, Mosses, Ferns and Submarines: I should be very glad you would undertake a Catalogue of all the Plants you have observed in Catalonia and on the Pyrenean Mountains and if to them you will add the Beasts, Birds, Fishes, Insects, Shells and Fossills, you would highly oblidge the whole World I doubt not but very particularly the Court of Madrid and it would be an Example for other Provinces of Spain to imitate and to incourage you to do it I will be at the [illeg.] to figure what you shall publish and dedicate the Tables to such Patrons as you shall direct or appoint me. I desire you will take this into Consideration and let me knowe your Mind at large which I will Comunicate to our Royall Society and if you desire it propose you for a Member which I beleive they will not refuse upon my Recomendation, Espesially if I can have yo $^{\mathrm{r}}$ promises of oblidging them with what I now propose: However you may be assured $\mathrm{S}^{\mathrm{r}}$ there shall [be] nothing [wanting] on my part to serve you my self to the utmost of My Ability earnestly desiring I may quickly and often hear from you which shall be retalliated by

Kind and Worthy $\mathrm{Sr}$

London Nov: 15: 1715

Your most hearty and affective Friend

James Petiver

The letter is interesting because it shows Petiver's extraordinary interest in Salvador affirming his connections with the naturalists at the Court in Madrid, mainly Burlet and Riqueur, with whom Petiver only had indirect contact through Lord Lexington. One should bear in mind that in the states under the Spanish Crown (and in particular the kingdoms 
under the Crown of Aragon, which were those that had supported Charles III of Habsburg against the Bourbon king Philip V), the movement known as "novatores" with which modern science began to be introduced, albeit with difficulty (López Piñero 1970: 387-388), made its appearance during the late seventeenth and early eighteenth centuries. The Salvadors formed part of this movement, which was particularly active in Valencia, Seville, Zaragoza and Barcelona in the form of informal social gatherings and "salons" in an extra-academic setting, given that the universities in the Hispanic kingdoms were, in general, strongholds of the fiercest resistance to change. ${ }^{19}$

“THE DEPLORABLE HISTORY OF THE CATALANS ... AND THEIR DEPLORABLE ALLIES"

Several other persons who are named in this letter, the Crowe family, Joseph Shallet and his trading companies, provide the opportunity to go more deeply into the economic and political relations of the period between Catalonia and England. The role of Mitford Crowe, in particular, was crucial at the start of the Catalan and English involvement in the War of the Spanish Succession. He was the English plenipotentiary who signed the Pact of Genoa, by virtue of which the Catalans undertook to support Charles III of Habsburg in exchange for military support from the English forces and their other allies.

Joseph Shallet (d. 1713) and Mitford Crowe (1669-1719) had been established in Catalonia for years and they had important interests there. They were partners in a firm involved mainly in the export of brandy. It was one of the most important trading companies in Barcelona in the late seventeenth and early eighteenth centuries, and as early as 1685 the company had a brandy distillery operating in Reus, near Tarragona (Andreu 1995; Fontana 2004). This had put them on good standing with the more influential business circles in Barcelona, in particular the big textile merchants who had also invested in distilleries to produce brandy for export to America (through the authorized ports of the Crown of Castile), as well as to England and Holland. The interest in maintaining exports to England and Holland may have been one of the determining factors in the Catalan business elite's preference for Charles of Austria over Philip of Anjou in the War of the Spanish Succession, given that political and diplomatic ties between the Spanish Crown and Louis XIV and France threatened to ruin the model for foreign trade that was being established and which greatly favoured the interests of the large traders (Fontana 2004). Moreover, Shallet acted as the English consul in Barcelona, and was succeeded in that post by one of Mitford Crowe's sons, George.

The privileged situation of these English traders in Catalonia and their network which included, amongst others, Prince George of Hesse-Darmstadt (the last Viceroy in Catalonia of the deceased Charles II of Spain) and a large part of the Barcelona and Catalan ruling circles, made Mitford Crowe the ideal candidate for English plenipotentiary in the Pact of Genoa. Elected to Parliament in 1702 as a member for Southampton, he had previously drawn up a report, at the request of Sydney Godolphin, First Lord of the Treasury, explaining the distribution of powers between the Crown and the institutions in the different Hispanic territories and, in particular, those of the Catalan institutions and the prevailing laws, customs and privileges in Catalonia (Porta i Berguedà 1984). Crowe's recommendation at the end of his report was that someone with full powers be sent to Genoa to negotiate an alliance with Catalonia. 
The government of Queen Anne took notice of Crowe's recommendation and the sovereign signed the requested powers designating Crowe as plenipotentiary to negotiate a secret treaty of friendship, alliance and protection between England and Catalonia. Unfortunately for the Catalans, the government that came into power in England in October 1710 did not honour its commitments in the Pact of Genoa and left them to their fate in the Treaty of Utrecht. An interesting pamphlet by J. Baker (1714), published in London, gives countless details of the proceedings of the English politicians at the time, the course of the war and how the Catalans were betrayed by their own sovereign and their allies in the Treaties of Utrecht (Baker 1714). The pamphlet's title, The deplorable history of the Catalans, sums it up succinctly.

After the signing of the Pact of Genoa, Mitford Crowe returned to Catalonia as Paymaster of the English forces who were fighting in support of Charles III of Habsburg, although he was almost immediately appointed Governor of Barbados, a post which he held from October 1706 to May 1710. Thus he was not in England in September 1708, as Petiver told Salvador. It appears that, on his return to England, Mitford Crowe had to face charges of bribery, of which he was exonerated. Amongst his friends was Jonathan Swift, who mentioned him in Journal to Stella (Swift 2009: letters 23, 24 and 32) as a colonel and new Governor of Jamaica in mid-1711.

\section{“BOTANOMASTICON CATALONICUM"}

Salvador replied to Petiver's letter of 15 November 1715, almost immediately on 4 January $1716 .^{20}$ This is one of the more interesting letters, given that it confirms Salvador's intention to write a "Botanomasticon Catalonicum". ${ }^{21} \mathrm{He}$ also responded positively to Petiver's suggestion about being proposed for election as a Fellow of the Royal Society of London. We do not know if Petiver made any attempt to nominate Salvador, who had become a corresponding member of Academie Royale des Sciences in Paris on 19 June 1715 through the resourcefulness of Antoine de Jussieu.

Sir and dear friend

I am very glad that you received the banker's draft given to me by Mr. Crowe in his brother's name: As for the 6 pounds sterling, Messrs Crowe, Speeman and Shallet told me it was in the name of Shallet and company. I drew the money back in September 1708 and I sent you the draft. [So] please go and see Mr. Shallet on behalf of the Crowes and Company so they can pay you that sum and, in case they refuse to pay you, I will let Mr. Crowe know so he can give me another. I received your letter dated April 25 from Madrid, in which there are two tables and a catalogue of plants, I will send you those that I can find here, together with the seeds, etc. that are drawn on the back of the letter: I would be very glad to receive at the first opportunity the books and catalogues that you mention and, if you would be so kind, you can address them to Messrs Shallet and Crowe, here in Barcelona, and give the parcel to his brother or Mr. Shallet in London. I would be very grateful if you could include some rare shells, ones from England and also the minerals and plants. If you can also send me the books for Mr. Burlet and Mr. Riqueur, I will see to it they are sent to them, as we are fortunate in having some friends who go there. I have just [illeg.] a crate to your address on the ship named The Henry, and the captain Henry Land, which goes directly to London, which was shipped by Mr. Crowe and who recommended the captain. In the crate there is a box for you, together with a parcel of plants and seeds; another for doctor Sloane whom I ask you to take it to; and another for Mr. Rand that contains more or less the same and I trust that you can also get it to him; I have addressed it to you the crate because of your honesty. I would be very grateful if you could send me your Herbarium Britanicum as soon as is it printed, together with the other new books. For all of this, I will pay the costs.

If you do me the honour of proposing me to your Illustrious and Celebrated Society, I will continue to communicate all of my discoveries to you and, as soon as I can, send you my Botanomasticon Catalonicum, but before that I must make a tour of different places in Catalonia that I have not been able to visit because of the 
war; and later on I will also send you catalogues of animals and minerals, etc. I have no doubt that with your means you will be successful: I will continue to write you often, as I trust you will do and, so that the letters do not get lost, under my address you can put the one that I have written at the bottom, which is that of one of my best friends who lodges in the house of the post-master: I also ask you to please deliver the enclosed letter to Mr. Squire ${ }^{22}$, apothecary, which is from his son, and I ask for news from him in your letters because it is a long time since he has written to his son. I beg to remain, with all my esteem, affectionately Sir

Your most humble and obedient servant and friend

Barcelona, 4 January 1716

Joan Salvador, Apothecary

Barcelona

Sir

Mossen Agustí Rovira

At the house of the Post-Master

In Barcelona

A hand-written footnote by Petiver shows that he received the letter on 3 February 1716, a month and a half before the arrival of Salvador's shipments sent the previous September. Nevertheless, three months later, after still not having received a reply from Petiver, Salvador wrote another letter $^{23}$ and enclosed a letter for the surgeon Robert Napier, who had taken part earlier in the exchanges between Salvador and Petiver. $^{24}$

\footnotetext{
Sir would send me some curios. In infinite gratitude.

Sir

From one who is truly your most humble and obedient

Servant and friend

Barcelona

6 April 1716

Joan Salvador
}

I have not heard from you in quite some time, nor received any reply to my last letter to you. I would be very grateful for a reply from you, together with confirmation that you received what I had the honour of sending you previously. Mr. Napier wrote to me from Algiers saying he was leaving for London and he asked me to write and address his letter to you. I would be very grateful if you could deliver the enclosed, and also if you

Petiver annotated this letter as received on 24 April (OS). Petiver's next reply bears the date of 29 May (OS), almost four months after receiving Salvador's letter of 4 January and one month after that of 6 April. ${ }^{25}$ Petiver acknowledged receipt of the shipment announced by Salvador in January. He reiterated most of the matters mentioned in the preceding letter and added some new ones. Of great interest is that he announced the enclosed shipment of the first part of Petiveriana seu naturae collectanea, in which he had published a list of sea creatures, fossils and minerals that Joan Salvador had sent to him, and also the forthcoming publication, in the following Petiveriana, of the list of plants from the Balearic Islands sent by Salvador a few years beforehand. The plants from the Balearic Islands were published in the third Petiveriana, the last that was to appear, just before Petiver's death, although a list of plants from Montserrat sent by Salvador does appear in the second one. Incidentally, the list of sea creatures, fossils and minerals that the letter referred to was published after another list of sea creatures, fossils, minerals and plants sent to Petiver by the Portuguese Pedro de Almeida, another distinguished and "curious" acquaintance of Joan Salvador mentioned by Petiver in his letter. ${ }^{26}$

Petiver expressed an interest in the plants from the Pyrenees described by the sixteenthcentury Catalan botanist Francesc Micó ${ }^{27}$ and published by Jacques Dalechamps in Historia 
generalis plantarum (which Petiver calls Historia lugdunensis, in all probability because of the place where the book was published).

Kind and Worthy Sr

London May 29th 1716

I had answered your last Letter much sooner but was willing it should be accompanied with an Aknowledgement of some part of what I have lately received from you, which you see I have already done so far as relates to the Crustaceous and Testaceous Animalls, Fossills, Minerals, and some Submarines. In my next I design to publish the Balearick Plants you have allready sent me and if you can add any more to them they shall allso be incerted. The day I received your Box I sent Sr Hans Sloane and Mr Rand what you had directed for them which I presume they have given you an account off. I have shewed our Royall Society what you have sent me and at the same time acquanted them with your Desirs and how well qualifyed you was to be one of our Members. I have not this Year the Honour to be of their Councill but perhaps before next Christmas I may, never the less I shall so far esponse your Interest as I hope in a little time to acquaint you when you will be admitted, in the interim they are in Expectation of your Botanomasticon Barcionense [sic] or at least you will send a part of which I will comunicate to them. I hope you will not this summer omitt whatever Frumenta, Gramina tam spicata quam paniculata, Junci, Cyperi et Cyperoidea \&c. which your Part afford, of all those I have now a Treatice a printing in relation to such as are Indigena of our Island and the like from you will be highly accetible with what other Plants may come in your way particularly the Pyreneans, a Catalogue of which I formerly sent you extracted out of the Historia Lugdanensis mostly discovered by that acurate Botanist of the last Age Doctor Mycone to which he hath added their figures, Caspar Bauhin in his Prodomus [sic] and Doctor Tournefort in his Institutions hath allso added many m[ore] which if I can obtain from you fine specimens off, I may perhaps give their Figures. If there be any Shells, Fossills, Mineralls \&c. in this half sheet I now send you, either from Don Pedro d'Almeyda, Pere Bonani's ${ }^{28}$ or your own that you desire samples off, be pleased to let me knowe it and I will forthwith send them with some others I am putting up for you from other parts which shall be sent you by the first ship that comes to Barcelona. I had no answer in my last about Doctor Nisole, ${ }^{29}$ his Botanicum Aviniense [sic] and if you have a Correspondence with him or can send to him pray let me know it as allso if there be any thing printing of the plants in Narbone and Province by one [illeg.] which some of our forreign journals mention and another I think of Trent or some other part of Italy, Whatever you can comunicate of this kind will be very acceptible and something of the same Nature you shall suddenly have from me in retalliation of your last favours who am

Worthy $\mathrm{Sr}$

With all affectionate love your hearty

Friend

to serve you

James Petiver

This letter did not arrive in Barcelona until the beginning of August, about the time Salvador returned to Barcelona from the Pyrenees, where he had spent a month collecting plants in what were the best conditions for alpine flora. Salvador must have been very keen to describe his trip to Petiver, and the coincidence of events resulted in two letters being sent in just one week, the first just before ${ }^{29}$ Salvador received Petiver's shipment, and the second ${ }^{30}$ just afterwards. The first, which according to a note written by Petiver, arrived on 23 August 1716, stated:

Sir

It has been some time since I have received news from you. I have had the honour to write to you on several occasions without having received any reply. I don't know if the letters have got lost on the way. I learnt that you have had the Collectanea Petiveriana published, I would be very grateful if you could send it addressed to Mr. Shallet or one other of our friends. I arrived back the day before yesterday from the Pyrenees with lots of beautiful plants; I will send all of the types to you, I ask you to remember me and to send me something for my cabinet. With true gratitude

Sir

Your most humble and most obedient

Servant and friend

Barcelona, on the 2nd

August 1716

Joan Salvador 
The second, which bears no date of receipt, but which was probably delivered to Petiver at the same time as the previous one, is much longer and mostly answers the questions asked by Petiver in his letter dated 29 May. Salvador reiterated his interest in being accepted by the Royal Society.

\begin{abstract}
Barcelona, 9 August 1716
Sir and dear friend

I just yesterday received your letter dated 29 May. I am very glad you received the box with everything I had the honour to send you. I am very grateful to you if you would obtain a good collection of different things that you say you will send on the first ship that leaves. I know from reliable sources that there are several in London that carry wheat and bring it straight here to Barcelona. They should leave soon and will transport the cargo sent to either Messrs Shallet and Crowe, Mr. Gregory Friend, an English merchant, or Messrs Fontaner and Jofre. I would be very grateful if you can send me whatever curious you have and especially so if you could include some sample of what appears in your Collectanea and that is numbered. I would also be very grateful if you could send me some specimens of all the species of terrestrial and sea shells from England; minerals, especially tin; petrifications, drugs, minerals and their parts, birds, \&c. I will send you a good collection and a catalogue of plants from the Pyrenees, having just returned from there a few days ago weighed down with plants that I collected, and I will share everything that I found with you. At the beginning of September, I trust I will journey through Spain and Portugal and I will share everything that I collect with you. I maintain a good correspondence with Mr. Nissole, he writes to me at every opportunity, although he has never told me about his Botanicon Avinionense or any other by anyone from Provence, such as Mr. Feuques. ${ }^{31}$ I thank you in advance for bearing me in mind if you have the opportunity of being present in the Royal Society. If you have printed anything else or if some new book on physics or the history of [? Woglufei] has been published, I will be most appreciative if you could send it and you believe that I am truly

Your most humble servant

And the other treatises of Joan Salvador

Mr. Scheuchzer
\end{abstract}

Since the end of the War of the Spanish Succession, Salvador had been able to resume contact with his French correspondents, including Nissole, who Petiver was frequently asking about, and Antoine de Jussieu, who had been a fellow student of Joan Salvador in Montpellier, with Magnol, and in Paris with Tournefort before the war in 1705. Antoine de Jussieu, botanical demonstrator at the Jardin du Roi from 1710 onwards, was appointed member of the Academie Royale des Sciences in 1715 and almost immediately he obtained Salvador's appointment as a corresponding member, as has already been mentioned.

In 1716, the president of the Academie, Abbe Jean Paul Bignon, proposed the idea to Philip of Orleans, the French regent during Louis XV's minority, of sending Jussieu to Spain and Portugal to complete the explorations made by Tournefort in 1680, 1687 and 1688. Jussieu proposed that the party should include his own brother Bernard (who later on became an important botanist but who, at that time, was only 17 and about to start his medical studies) as an apprentice, Philippe Simonneau, a painter and engraver from the Academie des Sciences, and Joan Salvador, described by Jussieu as "reconnu pour le plus célébre botaniste de ce royaume". Salvador participated in the expedition between Wednesday 7 October 1716 and Sunday 30 May 1717. His absence from Barcelona in part explains the temporary break in the correspondence between himself and Petiver.

TRAVELS THROUGH SPAIN AND PORTUGAL (1716-1717)

A few days before Salvador wrote to Petiver on 9 August 1716 (NS), Petiver had written a letter $^{32}$ which we only know about from a copy (which is difficult to read) in one of Petiver's 
letterbooks. Petiver grasped the opportunity of their mutual friend, the military surgeon James Campbell ${ }^{33}$ travelling to join the British garrison in Minorca, to send Salvador the first part of Petiveriana seu naturae collectanea (Petiver 1716a) in which he had included, amongst other things, a list of sea creatures (and some terrestrial molluscs), fossils and minerals sent to Petiver by Joan Salvador. This publication is not currently listed in the Salvador library, although the second part is (dated 1716, like the first (Petiver 1716b)), in which there is a list of plants from the mountainous area of Montserrat that was also sent by Salvador.

Mr John Salvadore

My Hearthy Friend

Altho I have had no Answer to my last dated the 29th of May, yet I cannot miss this opportunity by our Worthy Friend $\mathrm{M}^{\mathrm{r}}$. James Campbell to send $\mathrm{y}^{\mathrm{u}}$ my Petiveriana I perfect. To $\mathrm{w}^{\text {ch }} \mathrm{I}$ have now added the first sheet of my Gramina \&c. Brittan or. Concordia as I hinted in my last, hoping $\mathrm{y}^{\mathrm{u}}$ will send me as I desired in my last [illeg.] of these grow att you as also $\mathrm{y}^{\mathrm{r}}$ Cyperoides \& Junci ${ }^{\text {ch }}$ I [illeg.] in my next sheet, you will also [illeg.] my Desiderata Plantarum Etruriae [illeg.] from the accurate Cesalpinus \& others I doubt not but you have Correspondents in those parts $\mathrm{y}^{\mathrm{u}}$ can supply it both with what no each want. I have therefore sent you 3 or 4 of them $\mathrm{t}^{\mathrm{e}}$ number $\mathrm{y}^{\mathrm{u}}$ will find of the Plantam Desideratam Monspelii one of $\mathrm{w}^{\text {ch }}$ I desire you will particularly transmit to Dr Nissole who I had formerly whish I have a Correspondence with. Pray let him know I am impatient to see his Botanicum Avignionense $w^{\text {ch }}$ I hear he has some time since published [illeg.] he with [illeg.] what I want of the Montpellier Plants \& in my next Petiveriana pray let him know I shall print such I have already received from him. About a [illeg.] since our Royal Society adjourned as usual for near 3 months, at their Meeting again I shall [illeg.] $\mathrm{y}^{\mathrm{r}}$ desires of being a Member $\&$ in the interim could with I might requaint $\mathrm{t}^{\mathrm{m}}$ with something I should before that service from you $\mathrm{w}^{\mathrm{ch}}$ with what I have already shown in my Petiveriana I, will be a great inducement to accelerate $y^{\mathrm{r}}$ Election, having [illeg.] acquainted $\mathrm{t}^{\mathrm{m}}$ they may by te next expect part of $y^{\mathrm{r}}$ Botanomasticon Barcinonense $\mathrm{w}^{\mathrm{ch}}$ I hope you will not fail off. I have ready for you the dry specimens of about 50 American Trees $w^{\text {ch }}$ are published in te sheet I have send you. To these

I shall add most of te Grasses in my Concordia with their printed Labels to each \& some other things mentioned in my last these shall come with $\mathrm{M}^{\mathrm{r}}$ Campbell's things ho has desired the care of transmitting them to you. Pray let me hear from you as soon as possible $\mathrm{w}^{\mathrm{ch}}$ will be highly acceptible to

Dear $S^{r}$

$\mathrm{Y}^{\mathrm{r}}$ most affectionate Friend \& very

humble Serv ${ }^{\mathrm{t}}$

London

Augt XI.1716

J. P.

Around one month later, in September, Petiver again wrote to Salvador to acknowledge receipt of his two letters sent at the beginning of August. ${ }^{34}$

My Worthy Friend

I have received your 2 last Letters by wich I am glad to understand you are retourned from this fertile Pyrenean Mountains well stored with great variety of plants. I hope one hearty Friend Mr Campbell has been with you to whom I gave some Papers and have since sent you with his things a Box in which are about 50 specimens of American trees with references to each in my Petiveriana prima, to these $\mathrm{I}$ have added $\mathrm{t}^{\mathrm{e}}$ seed and fruit of above 30 of the same trees as allso near a 100 Grasses according to the method in my Concordia Graminum, Muscorum, \&c. Britanicum Which I have allso sent you. You will allso find near 20 American Coralls, Sponges, and other Submarines wich I hope will very well [illeg.] you. There are allso a score of Amerian [sic] shells and some from Lisbon all which I send you a Catalogue of inclosed and to such as you see Dr Nissole or Riqueur added I have sent you Duplicates for them and desire you will give them a Catalogue of them as I have promised them you would under the same Numbers I send yours and have marked each under the innitiall letters Viz N or R. This Box mailed J. S. I have this weeke put into Mr Barlows hands to you with $\mathrm{Mr}$ Campbells goods who has promised forthwith to transmitt it to you. In my Collectanea $2 \mathrm{da}$ I have nominated all the Plants you sent me gathered on Mount Serato and I impaciently expect what you can spare me out of your Pyrenean Cargo. I should have been very glad if you had filled a whole sheet of paper with a Catalogue of the Plants, Insects \&c. you there observed for a whole sheet of paper cost me but one shilling and six pence, and 
your last those and what you have me with since in the journey you intimated to me you was then a [illeg]. To show you what Spanish plants will be welcome to me I have extracted a list of such I should be glad to have samples of from Clusius his history ${ }^{35}$, I hope you will send me most of these Pyrenean Plants which Myconus has figured in the historia lugdunensis, the rest are in the Schola Botanica ${ }^{36}$ et Institutiones Rei Herbarij Tournefortij. ${ }^{37}$ I expect with impatience to hear largely from you concerning what you have lately got and what I may expect from you which I shall incert in my next Collectanea after I receive which pray let be with all speed and against that time I will have another Cargoe for you who am $\mathrm{Sr}$

Yr Most Humble Servt James Petiver

On the back of the letter and also on a second sheet, which also served as the envelope, is a list of over a hundred plants that Petiver hoped Salvador could provide and notices of the shipments that James Campbell had to take, one for Salvador and three more for Nissole, Riqueur and Langlade.

$\mathrm{S}^{\mathrm{r}}$ I desire you wile forward those to $\mathrm{D}^{\mathrm{r}}$ Nissole \& Mons $^{\mathrm{r}}$ Ricqueur Apothecary at Madrid \& $\mathrm{D}^{\mathrm{r}}$ Langlade $\mathrm{w}^{\text {ch }}$ you may inclose in Ricqueur's as soon as possible having already given advice of them

Vale [illeg.] sum

In particular, he made a point of a dozen plants described by Micó (Dalechamps 15861587):

Plantae Barcinonenses desiderata D. Mycone prime detecta Histor. Lugdun.

Cichorium strumosum Lugd. 560. Porcellanes dictum

Senecionis genus Myconi 577

Mentha saracenica species altera 672. Herba del moro. In colis Pyrenaeorum. Flor. Jul \& Aug. Pratis aq.

Parthenium smierophyllon 954. Imis Montium frigid.

Cneorum nigrum 1364. Florib. Pala marina. Barcin.

Thymelaea species 1668. Mierda-cruz rusticis.

Lilium polyrrhizon 1496. Montosis humidis.

Ornithogalum magnum 1583. Segetibus.

Arisarum angustifolium 1600.

Coix Myconi 1625. Hoc valde gratae erunt [ceteris].

As Salvador's travels around Spain and Portugal lasted almost eight months, this letter most probably reached Barcelona after Salvador had left and he would not know about it until he returned. Petiver did not receive any further news from Salvador until 25 June 1717 (see below: p. 00), when he received a letter sent from Lisbon. In the meantime, in March and not having received a reply to his previous letter, Petiver wrote again repeating most of the list of plants from the previous letter, and in April he expressed his surprise at Salvador's silence, in a letter to James Campbell.

Before reaching Lisbon on 20 January 1717, the travellers went as fast in their carriage as the highways at the time would let them. Whenever they wanted to explore a place that they considered interesting, they took two saddled mules that they had, in addition to the pack mules, and wandered off the main route meeting up again with the carriage at an agreed place. They hardly ever got delayed for more than a day, and it was only in cities like Alicante, Malaga, Cadiz and Seville where they stayed more than two days, probably because they were always busy preparing packages with the specimens they had gathered to be sent on to Barcelona and Paris. It was obviously unrealistic for them to follow any mail arriving for them in Barcelona after their departure and it was only when they reached Lisbon, that they had the opportunity of writing to their correspondents to reassure them after their long silence. 
Salvador wrote a brief letter to Petiver during his second stay in Lisbon (18 February-31 March 1717). ${ }^{38}$

Sir

Having gathered herbs over a large part of Spain, we began to do so in Portugal, where we found many plants and we will continue on to Galicia, Castile, \&c and then head to Barcelona. So when we reach Barcelona, if all the shipments that we have been sending have arrived, I will share with you all of the plants from Spain and Portugal, as well as stones, seeds and other things. I also hope that, on my return, I shall find something that you have had the honour to send me. If we had been able to collect plants on the Rock of Gibraltar we would have found something interesting, but the Governor ${ }^{39}$ is so zealous about the fortifications that he did not let us climb it, saying that from up there they are exposed and everything can be seen. In the end, we had to leave, which was most annoying. When I return to Barcelona I shall write to you. Believe me I am always, Sir, your most humble and obedient servant and friend. Lisbon, 26 February 1717. Joan Salvador.

Salvador explained the incident in Gibraltar in more detail in his travel diary. They had reached the gates of Gibraltar on Thursday 10 December but these had been closed at sun down by the British garrison and they were unable to enter until the next day. They went to visit the Governor, who initially promised that he would let them climb the Rock and even provide them with a guide, but he later went back on his word because he suspected them of being spies. He would not even let them go up to the Shrine of Our Lady of Europe. From the details on the defences of Gibraltar that Salvador recorded in his travel diary (Salvador I Riera 1972: 56), which were merely the result of some observations during a rushed morning by a man who was supposedly not interested in warfare, we suggest that the Governor was right.

The English have fortified Gibraltar very strongly, and they have more than three hundred cannons, lots of mortars and other war provisions. At Wolf's Leap, which is where one can climb higher up on the crag, there is a battery of twenty cannons that defends the avenue. Nowadays it is known as Queen Anne's Battery; down by the sea there is also another very good battery.

A note written by Petiver, at the foot of Joan Salvador's letter from Lisbon, shows that he received it on 25 June 1717, a few weeks after the trip through Spain and Portugal had ended. It seems that Joan Salvador did not take full advantage of opportunities to send his mail directly by sea between Lisbon and London that he undoubtedly could have done, but that he must have included it in one of the overland shipments that he sent to Barcelona and Paris together with other mail of his and from Antoine de Jussieu. It is the last of Joan Salvador's letters that are in the Sloane papers, although as will be seen below there is evidence that Petiver received at least one more.

While Salvador and the Jussieu brothers were on their travels in Spain and Portugal, Petiver must have become increasingly impatient so in March 1717 he wrote to Salvador; two versions of this letter are extant ${ }^{40}$, both accompanied by a list of 124 Hispanic plants. One version is undated and the last paragraph and the signature are missing. The more complete version is dated and signed so was probably sent as a letter, with the other one enclosed with the shipment that it refers to. ${ }^{41}$

London March 15 1716/17

My Worthy Friend

In September last I wrote largely to you to wich I refer you and now every day impaciently expect a chargoe of your Pyrenean Plants, Insects and what else you have collected in those celebrated mountains, $\mathrm{t}^{\mathrm{t}}$ I may whith your leave insert them in my next Collectanea, I have already printed in my third the Balearick Plants $\mathrm{Y}^{\mathrm{u}}$ sent me collected in Minorca. I have finished a second sheet of my Concordia Graminum which contains the Cyperi, Cyperoides, Junci et Gr. Juncea, I hope of all these tribus [sic] you will sent me a particular collection, of such you have either collected $y^{r}$ self or procured from other Botanick Friends which you correspond withall. And to shew you how much this Tribe is my beloved besides the graminum Italiae Icones wich I have coppied from Barrelier, I have in my $3^{\text {rd }}$ Collectanea given you a Catalogue of all the rare and non descript Grasses, Cyperi et 
Junci extracted from Grisley Viridarium Lusitanicum $w^{\text {ch }}$ I will send you by the next and I doubt not but many of them may fall in your way or procured by you from thence. I have also just finished the figures of all our Papiliones Britannicae qui tantum die volant et habent antennas clavatas, ad distinguendum a Phalenis quae vesperi et nocte visuntur, Antennis acutis seu plumosis. These are contained in six Tables and are in number about eighty, whereas the Phalenae are above 4 times that number. Viz: about 300 great and small. These figures I will send you and the Insects themselves and many other things as soon as I have received $\mathrm{y}^{\mathrm{r}}$ Pyrenean

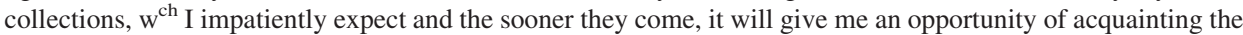
Royall Society of $\mathrm{y}^{\mathrm{r}}$ performances towards the compleating $\mathrm{y}^{\mathrm{r}}$ Botanicum Catalonicum and a further inducement to have you the sooner chosen a member of us, wch I hope I shall effectually perform they having done me the Honour to admitt me one of the Privy Council for this year, and therefore that I may not loose it let me hear quickly and often from you that I may the sooner print $\mathrm{w}^{\mathrm{t}}$ I receive to make them sensible of $\mathrm{y}^{\mathrm{r}}$ abilities. I have annexed a Catalogue of such spanish Plants which I should be glad to have the specimens of from you, whose Authority will confirm me in divers of them I already have but am in some doubt [illeg.]. The [illeg.] like lists if you please to send forthwith furnish you with them desiring a more frequent commutation with you, then which nothing can be more Acceptible Dear $S^{r}$

to $\mathrm{y}^{\mathrm{r}}$ humble servant

James Petiver

Petiver sent this letter during the last few days of Salvador's (and the Jussieus') stay in Lisbon before they travelled to the north of Portugal and Galicia, although he was still unaware that his correspondent was away on a trip. He even expressed his surprise at Salvador's long silence to other people, in particular James Campbell. The letter, was posted on 23 April 1717, according to a note in Petiver's letter book, and demonstrated Petiver's anxiety during the first few months of $1717 .^{42}$

\footnotetext{
$\mathrm{M}^{\mathrm{r}}$ James Campbell

Surg $^{\mathrm{n}}$ to $\mathrm{t}^{\mathrm{e}}$ Fort at

Port Mahon

My Worthy Friend

not sent [till]
}

Apr.23.1717 ... M ${ }^{\mathrm{r}}$ Clark

I hope long ere this you have re ${ }^{\text {cd }}$ mine of Sept.13 by $\mathrm{M}^{\mathrm{r}}$ Barlow with $\mathrm{t}^{\mathrm{e}}$ Box for our Curious Friend $\mathrm{M}^{\mathrm{r}}$ Salvadore $\mathrm{w}^{\mathrm{ch}}$ I doubt not of $\mathrm{y}^{\mathrm{r}}$ speedy convoyance to him. I herewith [illeg.] you on acknowledgment of $\mathrm{t}^{\mathrm{e}}$ Corall you was pleased to give me before you left [illeg.] also a Catalogue of Barbarich plants for $\mathrm{t}^{\mathrm{e}}$ [illeg.]rging of $\mathrm{w}^{\mathrm{ch}} \mathrm{I}$ rely now wholly on you \& your promise $\mathrm{w}^{\text {ch }}$ I have given $\mathrm{t}^{\mathrm{e}}$ [illeg.] to expect [illeg.] you may see in my printed Collectanea for you to my last in desiring $\mathrm{w}^{\mathrm{t}}$ Varieties of Corall Spongies \& other sea productions $\mathrm{y}^{\mathrm{r}}$ shores [illeg.] I hope by $\mathrm{t}^{\mathrm{e}}$ next shiping you will store me with them. I am very sensible how greatly you may add to $\mathrm{t}^{\mathrm{e}}$ numbers I have here printed \& beg $\mathrm{y}^{\mathrm{u}}$ [illeg.] think none too comon but send whatever $\mathrm{y}^{\mathrm{u}}$ must with others in Flower Seed or fruit \& be [assured] the most comon Grass, Rush, Moss, Thrift or Fern will be as acceptible as a finest plant then not having one of any of these sorts in this printed Collection $\&$ when $\mathrm{y}^{\mathrm{r}}$ hand is in if you please to gather 3 or 4 sprigs of every sort I [illeg.] able to return you some of them [illeg.] with references to $\mathrm{w}^{\mathrm{t}} \mathrm{D}^{\mathrm{r}}$ Raw or shall print of them. I beg $\mathrm{S}^{\mathrm{r}}$ I may affectually \& suddenly hear from $\mathrm{y}^{\mathrm{u}} \&$ in return be pleased [illeg.] to [illeg.]

Worthy $\mathrm{S}^{\mathrm{r}}$

$\mathrm{Y}^{\mathrm{r}}$ most humble serv ${ }^{\mathrm{t}}$

J. P.

Just a few days before receiving the letter sent by Salvador from Lisbon, Petiver sent him another, which was copied into a letterbook. ${ }^{43}$

\section{$\mathrm{D}^{\mathrm{r}}$ John Salvadore}

So perfect, fine \& carefully dryed as so consumate a Botanist as $\mathrm{y}^{\mathrm{r}}$ self would have taken [illeg.] pains to have done but surgeons are most of them ignorant in te knowledge of Plants \& lazy nevertteless it is with no small charge $\&$ difficulty $\mathrm{t}^{\mathrm{t}} \mathrm{I}$ procure $\mathrm{t}^{\mathrm{m}}$ in te state $\mathrm{t}^{\mathrm{y}}$ are in $\&$ too often do I receive Collections from both te Indies allmost wholly rotten so $\mathrm{t}^{\mathrm{y}} \mathrm{I}$ am fain to patchup a great many specimens $\mathrm{w}^{\text {ch }}$ gives me no small trouble $\&$ much to my regrett.

However you may be assured I will send you te best I have \& more you cannot expect \& could wish in return I had $\mathrm{t}^{\mathrm{e}}$ same from you collected in Peru, Chili, Mexico or any parts of $\mathrm{y}^{\mathrm{r}}$ own foreign settlements $\mathrm{w}^{\text {ch }} \mathrm{I}$ cannot 
but think you might easily procure from $\mathrm{t}^{\mathrm{e}}$ many missionaries or Fathers $\mathrm{w}^{\mathrm{ch}}$ reside in these parts \& particularly sprigs of $\mathrm{t}^{\mathrm{e}}$ [illeg.] Peruv. Paraguay \& divers other Medicinal Trees \& Herbs.

You would do a thing very worthy of $y^{r}$ selfe \& $t^{e}$ World's acceptance to settle a correspondence amongst te Physitians \& Fathers in Mexico \& $\mathrm{t}^{\mathrm{e}}$ adjacent provinces to send you such Plants [? these] parts afford $\mathrm{w}^{\mathrm{ch}}$ might prove a great illustration to $\mathrm{t}^{\mathrm{e}}$ History of Hernande $\mathrm{z}^{44}$ whose descriptions are short \& Figures mean, however many of $\mathrm{T}^{\mathrm{m}}$ might be retrived by sending [illeg.] own a Catalogue of them under te Mexican names by $\mathrm{w}^{\text {ch }}$ Hernandez has given them.

I shall $\mathrm{S}^{\mathrm{r}}$ dine to [illeg.] \& drink $\mathrm{y}^{\mathrm{r}}$ health with our Worthy Friend $\mathrm{M}^{\mathrm{r}}$ Georges Hay who I suppose will accompany this with a Letter from himself, we often give our selfes $\mathrm{t}^{\mathrm{e}}$ pleasure of talking of you $\mathrm{w}^{\text {ch }}$ makes me wish for the hapiness he has had of $\mathrm{y}^{\mathrm{r}}$ Conversation \& a week herborizing with you on the Pyrenean \& other Mountains to see my dearly beloved in their native places but since I am deprived from $\mathrm{y}^{\mathrm{r}}$ Felicity \& now for ever $\mathrm{t}^{\mathrm{e}}$ expectations of it dayly decaying \& growing more infirm, I must be contented to sit at home in hopes my kind friends will furnish me from abroad \& you particularly with $\mathrm{y}^{\mathrm{r}}$ last years acquisitions \& what you have so lately added to them $\&$ in expectation of their quick arrival I shall forthwith prepare for you a collection of Malabar Trees \& Herbs $w^{\text {ch }}$ I hope will please you \& merit whatever you shall be so kind to favour me with $\&$ as I am now leaving off, $\mathrm{t}^{\mathrm{e}}$ cares of the World so $\mathrm{t}^{\mathrm{e}}$ speculation of Nature shall take up its room \& therefore beg we may have for $\mathrm{t}^{\mathrm{e}}$ future a more frequent commutation \& Correspondence together, then $\mathrm{w}^{\mathrm{ch}}$ nothing can be more acceptible to

Worthy $\mathrm{S}^{\mathrm{r}}$.

$\mathrm{Y}^{\mathrm{r}}$ most affectionate

Friend

London Jun. 20. 1717.

Ja: Petiver

As mentioned above, we were unable to find any letter from Salvador to Petiver subsequent to the shipment from Lisbon in February 1717, although the final letter from Petiver explicitly referred of a letter sent by Salvador in August 1717 (and received by Petiver in November), the content of which we only know from what Petiver mentions. By this time, however, Salvador's relationships were much more extensive than at the beginning and the shipments sent by him to London were not all for Petiver. For example, amongst Sloane's papers we found two short memoranda by Salvador referring to a shipment of plants from Spain and Portugal addressed to Sloane through a London merchant. ${ }^{45}$ From what Petiver stated in his last letter the shipment included plants not only for Petiver, but for other naturalists in London known to Salvador, such as Isaac Rand.

Sir

I am taking the opportunity of an English ship that is going directly to London to share with you some plants that we brought back from our trip through Spain and Portugal. I trust that you will find some that are to your liking. I will do my best to add something else when I have everything in order. As always, Sir, your most humble and obedient servant. Barcelona, 14 October 1717.

Joan Salvador, apothecary.

Sir

Three or four weeks ago, on the ship called the Florence Galley, captain Michael Magdonel ${ }^{46}$, I sent a package in which you will find some dried plants that we brought back from our trip through Spain and Portugal. I trust that you will find some that are to your liking. It is addressed to Mr [? Wyatt] merchant of London. When the ship arrives, please go and ask him for it and he will give to you. I would be very grateful if you could share something you may have with me. Please believe I am truly, Sir, your most humble and obedient servant. Barcelona, 13 November 1717. Joan Salvador. Apothecary.

The part of this shipment that was for Petiver was undoubtedly the last piece of news he would receive from his colleague in Barcelona. The following letter was Petiver's last one to Salvador, penned less than three months before his death on 2 April $1718 .{ }^{47}$

Worthy Sr.

$\mathrm{Y}^{\mathrm{rs}}$ of Augst last I received not till 4 or 5 days since but however am glad you have not forget me, about 6 weeks before the date of yours I wrote you a long letter $w^{\text {ch }}$ I fear you had not then received altho 
sent \& accompanied $\mathrm{w}^{\text {th }}$ one from our Worthy Friend $\mathrm{M}^{\mathrm{r}}$ George Hay because you make no mention of either in it I desired you would send me a Journall or abstract of what you observed in $y^{\mathrm{r}}$ Travells thro Spain \& Portugall $\mathrm{t}^{\mathrm{t}} \mathrm{I}$ might lay them before the Royall society \& I wish you had done it in $\mathrm{y}^{\mathrm{r}}$ last letter $\mathrm{w}^{\mathrm{ch}}$ would have come very opportunely the 30th of this month being our anniversary day for Electing President officers Councill \& Members. however I hope you will not faile to doe it in $\mathrm{y}^{\mathrm{r}}$ next for a whole sheet of paper [illeg.] me nor more by Post than the least [illeg.] you can with on, \& we pay as much for the outer cover $\mathrm{w}^{\text {th }}$ is only the superscription (if it is separate from the letter) as if it was a whole sheet $\&$ as much for the letter beside therefore as I set you an example of long letters I hope you will doe the same by me, for I know $y^{\mathrm{r}}$ observations are many \& curious \& will be not less acceptable to our Royall Society than my self

Nov. 25. 1717

Sr.

The last Week Mons ${ }^{\mathrm{r}}$ Tourneforts Voyage to the Levant in 2 volumes in $4^{\text {to }}$ came to my hands, a work I have a long time desired to see but I find it falls much short of my expectations $\mathrm{w}^{\text {th }}$ his [? Cat.] in wich there is the Names of above 1300 Plants of $w^{\text {ch }}$ in both volumes he has not given us the Figures of quite 40 soe that there remains above 1200 behind \& these he has published are not the most rare. I should be glad to meet you in Paris to see the paintings of the Rest \& the designs of Pere Plumier but this is only the flight of a wish. I shall be glad to know if at the Escuriall or any other part of Spain you saw or heard of the paintings of Hernandez his Naturall History of Mexico $w^{\text {ch }}$ cost the K. of Spain soe much money. I hope this Journey has given you an opportunity att Madrid or elsewhere to settle a Correspondence (as I hinted to you in my last) $\mathrm{w}^{\text {th }}$ some curious persons as the Fathers Missionaries \&c in Mexico, Peru, Chile, the Philippines \&c. by $w^{\text {ch }}$ you might make considerable discoverys in Nature. Pray did you see att Madrid Mons. Riequere [sic] \& let me know if you have frequent opportunities of sending to him.

Dec. 5. 1717

Dear $\mathrm{Sr}$

I have now the satisfaction since the last written to acquaint you $t^{t}$ I have received your Collections of Plants \&c $w^{\text {ch }}$ our Worthy Friend $S^{r}$ Hans Sloan took care off, I having sent him \& $\mathrm{M}^{\mathrm{r}}$ Rand $\mathrm{y}^{\mathrm{r}}$ Letters of advice, $\mathrm{w}^{\mathrm{ch}} \mathrm{y}^{\mathrm{r}}$ Friend a Marchant a Neighbour of mine brought me, $\mathrm{M}^{\mathrm{r}}$ Rand came the next week to acquaint me, he had alsoe received his collections \& was in hopes of some seeds $\mathrm{w}^{\text {ch }}$ are more particularly his Province he [under]standing the culture \& raising of seds nicely well. I told him I had not received from you above 4 or 5 sorts of seeds $w^{\text {ch }}$ I gave him a share of $w^{\text {ch }}$ he was pleased with.

I must own my self highly obliged to you for the great variety of specimens you have sent, \& am very glad to see some of Grisleys Viridarium amongst them \& daily value his Book the more for him. You will find in one of my Collectanea, a Catalogue of most of his rare \& ND Frumentacea Gramina Cyperi et Junci $\mathrm{W}^{\text {ch }}$ Family I find you have made the least collections off, but hope you will more nicely prosecute them since you see they have soe great variety. In my next Collectanea I designe an account of all the Plants you have sent me or hitherto discovered on this celebrated mountains the Pyreneans, If I am not prevented by $\mathrm{y}^{\mathrm{r}}$ not sending me a catalogue as you promised in your last should be by the Post $\mathrm{w}^{\text {ch }}$ I realy expect \& hope amongst them you have found most of these $\mathrm{w}^{\mathrm{ch}} \mathrm{D}^{\mathrm{r}}$ Mycone has figured in the Hystoria Lugdunensis, for in Botany untill we have cleared the Plants deleivered to us in the last \& preceding ages we shall never be certain what is New, soe that to me its greater satisfaction to discover an old plant than to New ones.

My Dear Friend I am sory to tell you that the Ill state of my health prevents my sending to you soe frecuently as I otherwise should, however depend on it, as my strength will give me oppurtunity, you shall hear from me, I have since the receipt of yours put up ready for you about 40 kinds of fruits, seeds \&c. which were growing the last summer in Jamaca [sic], these shall be sent by the first ship \& by all oppurtunities [illeg.] endeavour to send you more or less as I am able having now almost [illeg.] done with Bussiness therefore shall dedicate the remainder of my days to the contemplation of God thro the manifold works of his Stupendious [sic] Creation. My Hearty Frind I pray God to give you health \& many years that you may prosecute with vigour these soe laudable studies, is the hearty wishes of as well as Prayers of

Dear $S^{\mathrm{rr}} \cdot \mathrm{y}^{\mathrm{r}}$ very affectionate Friend

James Petiver

London Jan. 10. 1718.

P. S. Amongst the Merchants who most send shipps between us \& Barcelona if you can recommend me to one who will take care to convey to you what from time to time I may have ready for you, I shall always put them in 
his hands as soon as ready for the Ill state of my health does not permit me to goe out above one or twice in a month soe that I took many opportunity of sending to you. $\mathrm{S}^{\mathrm{r}}$.

$\mathrm{Y}^{\mathrm{rs}}$

J. P.

\section{CONCLUSION}

In this stage of the correspondence between Joan Salvador and James Petiver, the increasing scientific maturity of Joan Salvador clearly comes across, with him merely depending on his London correspondent to fulfil his ambition of being accepted by the Royal Society (an ambition that would never be fulfilled in spite of James Petiver's repeated promises). Petiver, on the other hand, tries to obtain through Joan Salvador more conversant communication with French scholars with whom he had lost contact during the War of the Spanish Succession.

The exchanges between the two correspondents were more harmonious and the two had more mutual friends than in the earlier period of their relationship. These were the most productive years in scientific terms of Joan Salvador, as he was appointed a correspondent of the Academie Royale des Sciences in Paris and he accompanied the Jussieu brothers on their trip to Spain and Portugal. Later on, he also collaborated with Le Masson du Parc in his study on fish. Petiver, on the other hand, was old and in the final years of his life although he was active until just before his death.

To sum up, we were fortunate to be able to find and reconstruct almost all of the correspondence between two naturalists who were typical representatives of the "Republic of Letters" of their time, and are of particular interest with regard to scientific activity in Barcelona in the late seventeenth and early eighteenth centuries.

\section{ACKNOWLEDGEMENTS}

The authors wish to acknowledge the help of Fundació Enciclopèdia Catalana (Barcelona) in the early stages of this work. It was later on (2003) partly supported by the SYS-Resource Project of the European Union with a grant to study Salvadorian materials in the Sloane Herbarium (Natural History Museum, London). We are also very grateful to the referees who read the initial versions of this article and for their remarks and suggestions. Our warmest thanks to Charles Southgate for his help in translating and checking the text.

\section{NOTES}

\footnotetext{
${ }^{1}$ The original text of each transcribed document is given. With regard to the dates of the correspondence transcribed here, one should bear in mind that the Gregorian calendar had still not been adopted in England in 17151718 and so the dates in the heading of each correspondent's letters relate to different calendars. The dates that are Old Style (OS), as used by Petiver, correspond to eleven days later according to the New Style (NS) used by Joan Salvador.

${ }^{2}$ J. Petiver (hereafter JP) to J. Salvador (hereafter JS), 25 April 1715 (OS): original ms, Institut Botànic de Barcelona: correspondence of Joan Salvador (hereafter IBB-JS).

${ }^{3}$ Jacques Barrelier (1606-1672) was a French doctor and naturalist who in 1635 entered the Dominican Order. Secretary to the Order's Master General from 1646 onwards, he accompanied him on his journeys in France, Spain and Italy. This allowed him to observe the flora in these countries and, when he finally took up residence in Rome in 1653, he prepared the manuscript and drawings for a work with the title "Hortus Mundi seu Orbis botanicus". Unfortunately, back in Paris, in 1672 he died of an asthma attack and shortly afterwards, most of his manuscripts were lost in a fire. Antoine de Jussieu saved an important number of the copper plates, which he published with his own comments in 1714 in Icones plantarum per Galliam, Hispaniam et Italiam observatae, from which Petiver obtained the engravings that he reproduced.
} 
4 This must have been the posthumously published Traité des fougères de l'Amerique (Plumier 1705).

5 The Office of the Royal Physicians, there being three physicians in all.

${ }^{6}$ In the Salvador collections today, there are eleven letters from Nissole, a copy of a reply from Joan Salvador and one from Jaume Salvador to him, two hand-written receipts from Nissole for different pharmaceutical products and an autographed copy of Dissertation botanique sur l'origine et la nature du kermes (Nissole 1714).

${ }^{7}$ Guillaume Nissole (1647-1734) was a French physician and botanist. His father and brother were, in succession, professors of Anatomy at the Faculty of Medicine in Montpellier from 1649 to 1689 and 1689 to 1726. In 1706 he entered the Société Royale des Sciences, Montpellier. He was a botanical demonstrator (1720-1721) at the Jardin des Plantes in Montpellier and he described a number of species in Memoires de l'Academie Royale des Sciences in Paris as well as those in the Société Royale des Sciences de Montpellier, although he never published the work attributed to him by Petiver.

${ }^{8}$ JS to JP, 8 September 1715 (NS): original ms in British Library, London: Sloane MSS 40 65, f. 230 (hereafter BL-Sloane). Letter noted as having been received by Petiver on 26 September 1707 (OS) (for the original text see Appendix pp. 00-00).

97 October 1715 in New Style.

${ }^{10}$ JS to JP, 10 September 1715 (NS): BL-Sloane 4065, f. 231.

${ }^{11}$ JS to Hans Sloane, 10 September 1715 (NS): BL-Sloane 4044, f. 94.

12 JP to JS, 15 November 1715 (OS): IBB-JS.

${ }^{13}$ In Theobalds Park (Hertfordshire), about 12 miles north of London.

${ }^{14}$ Captain Jezreel Jones (d.1731), naval officer, diplomat, naturalist and man of letters, one of the first scholars of the Tamazight (Berber) language of Morocco. He was the secretary to Sir Paul Methuen when he was the ambassador to Lisbon and Madrid. Taking advantage of his knowledge of the Arabic and Tamazight languages, he also carried out diplomatic functions as the British envoy to the Sultan of Morocco to secure provisions for Gibraltar when the city was occupied by the English in 1704 .

${ }^{15}$ Mr Methwyn was undoubtedly Sir Paul Methuen (1672-1757), an English politician and diplomat, ambassador to Madrid between 1714 and 1716. Methuen had previously been the representative (between 1697 and 1705) of Queen Anne to the court of Charles III of Habsburg and took part in his landing in Barcelona in 1705, so it is possible that, during his stay in Barcelona, he may have associated with the Salvadors in the court circles.

16 This no doubt refers to Isaac Rand (1674-1743), an apothecary like Salvador and Petiver and the latter's collaborator at the Chelsea Physic Garden of the Worshipful Society of Apothecaries of London, of which he was the director following the death of Petiver. It appears that the relationship between the two London apothecaries was not at its best at this time.

${ }^{17}$ As we shall see, Petiver was concerned about encouraging good relations between his Catalan correspondent and the more significant personages at the Court in Madrid within the scope of his interests.

${ }^{18}$ A French doctor residing in Spain and correspondent of Petiver, about whom we were unable to find any more information.

${ }^{19}$ For example, a description by Sir Francis Willughby on the occasion of his visit to the University of Valencia in 1664 was still perfectly valid 50 years later (Ray 1673):

I heard a professor read logick. The Scholars are suficient insolent and very disputatious. One of them ask'd me. Quid est Ens universale? and whether I was of Thomas Aquina's opinion? Another Quid est genus? None of them understood any thing of the new philosophy, or had so much as heard of it; none of the new books to be found in any of their booksellers shops; in a word, the university of Valence is just where our universities were 100 years ago.

${ }^{20}$ JS to JP, 4 January 1716 (NS): BL-Sloane 4065, ff 236-237.

${ }^{21}$ Pourret (1796) gave the complete title of this work (it appears that he never saw the manuscript, although Cosson had seen it in 1754) copied, according to him, on a sheet of paper, now lost:

Botanomasticon Catalonicum, sive catalogus plantarum quae in Cataloniae montibus, sylvis, pratis, campis et maritimis sponte nascuntur; tum illarum quae aliqua cultura indigent. Cum denominatione locarum ubi proveniunt ac mensium quibus vigent, et florent. Nec non virtutes juxta neoticorum principiis a celeberrimis auctoribus dessumptae complurimaeque propio experimento confirmatae exponuntur. Variis iconibus descriptionisque illustratur. 
The title is explicit enough, and the loss of what would have been the first work on the flora in Catalonia, with a series of significant figures and data on each of the plants appearing in it, including the place where they were from and their therapeutic properties as confirmed through the experiments of the author himself, is a great shame.

${ }^{22}$ William Squire was an apothecary friend of Petiver's. In 1710, he was appointed master apothecary to the campaign hospitals of the English forces fighting in Catalonia in support of King Charles III of Habsburg, and he stayed in Catalonia until they retreated with the signing of the Treaty of Utrecht in 1713.

23 JS to JP, 4 January 1716 (NS): BL-Sloane 4065, f. 244.

${ }^{24}$ Robert Napier was an English military surgeon. At least between June 1712 and October 1714, he was surgeon's mate at St Anne's Fort in Port Mahon with the surgeon James Campbell, another mutual friend of Petiver and Salvador. According to Dalton (1912; Mata 1994), these positions at St Anne's Fort were no other than a bureaucratic front for salaries with no specific function, as the fort in question never became anything more than just a project, of which only a fragment of the wall was built. At the beginning of 1716, Napier must have been returning to England or he had already returned, which is why Joan Salvador had enclosed a letter for him that refers to Petiver.

25 JP to JS, 29 May 1716 (OS): IBB-JS.

${ }^{26}$ Pedro Miguel de Almeida Portugal e Vasconcelos (1688-1756), Count of Assumar, was a Portuguese noble and soldier and a science enthusiast. In 1705 he accompanied his father, the Portuguese ambassador to the Court of Charles III of Habsburg in Barcelona, and it is highly possible, given his interest in natural history, that he would have frequented the gatherings in the back room of the Salvadors' establishment, at least between 1705 and 1708 , prior to joining the army. In 1717 Pedro de Almeida was appointed governor of São Paulo and Minas Gerais, where he stayed until 1721, and later on (1744) the Portuguese Viceroy to India. In 1748 he received the title of Marquis of Alorna for having reconquered the Alorna Fort, near Goa.

${ }^{27}$ Francesc Micó (1528-1576), better known as Franciscus Myconus, was a Catalan physician and botanist. He worked for some time in hospitals in Guadalupe (Extremadura, Spain) together with Francisco Hernàndez (15151587), and he was a correspondent of Jacques Dalechamps (1513-1588), to whom he provided samples and seeds of plants from the Americas as a result of the good relations that he maintained with the physicians and apothecaries at the Court of Philip II. In Historia generalis plantarum (1586-1587), Dalechamps published 25 species, the majority from the Pyrenees, identified and described by Micó, who never published any work on botany, although he did publish one interesting work entitled Alivio de los sedientos (1572) on the therapeutic use of ice and cold water.

${ }^{28}$ Filippo Buonanni (1638-1725) was an Italian Jesuit and author of Ricreatione dell'Occhio e della Mente nell'osservation' delle chiocciole $(1681,1684)$, considered to be one of the foundation works of malacology. He was the archivist of his Order's seat in Rome and, in addition to his malacology work, he published learned works on numismatics, musical instruments and other subjects. From 1698 onwards, he was the conservator at the Kircherianum Museum, the cabinet of curiosities collected by the German Jesuit Athanasius Kircher, of which he published the catalogue.

29 JS to JP, 2 August 1716 (NS): BL-Sloane 4065, f. 256.

${ }^{30}$ JS to JP, 9 August 1716 (NS): BL-Sloane 4065, f. 257.

${ }^{31}$ Pourret (1796) mentioned a certain Mr de Feuques as one of Joan Salvador's plant-gathering companions in Provence during the summer of 1705; although we were unable to find any more information on this person.

32 JP to JS, 11 August 1716 (OS): BL-Sloane 3340, ff 25v-257v.

33 James Campbell was an English surgeon with the British garrison in Minorca who, in the summer of 1716, returned to the island following a stay in England. His presence is recorded at St Anne's Fort from at least June 1712 to October 1714 together with James Napier (see note 25 above), who figured as a surgeon's mate, although according to Dalton (1912; Mata 1994), these positions at St Anne's Fort were no other than a bureaucratic front for salaries with no specific function, as the fort in question never became anything more than just a project, of which only a fragment of the wall was built. He was a friend of James Petiver and it seems that he also associated with Joan Salvador and Jan Lecaan. Petiver mentioned him as being a friend, not just in this letter, but also in Petiveriana seu naturae collectanea III (1717), in which Petiver published a list of plants from the Balearic Islands sent by Salvador and also Boucher, together with a second list of plants, again from the Balearics, sent by Boucher and Campbell.

34 JP to JS, not dated (probably September 1716): IBB-JS. Petiver's letter was not dated although from the context established with earlier letters and a reference made in a later letter (part of the content of which coincides with that of this letter) to a letter sent "in september last", we believe that there is no doubt about the date of September 1716.

${ }^{35}$ Clusius (1576). 
36 Tournefort (1689).

37 Tournefort (1700).

38 JS to JP, 23 February 1716 (NS): BL-Sloane 4065, f. 277.

39 At that time the Scot David Colyear, first Earl of Portmore (c.1656-1730).

${ }^{40}$ With very few variants, both of which are conserved at the Institut Botànic de Barcelona.

${ }^{41}$ JP to JS, 15 March 1717 (OS) (and copy of the same): IBB-JS. We chose to transcribe the more complete version (omitting the list of plants) and complete words were selected instead of abbreviations where these appeared in either of the two versions, which were disregarded.

42 JP to James Campbell, 23 April 1717 (OS): BL-Sloane 3340, ff 311v-312r.

43 JP to JS, 20 June 1717 (OS): BL-Sloane 3340, ff 329v-330r.

${ }^{44}$ Hernández (1648).

45 JS to Hans Sloane, 14 October 1717 (NS) and 13 November 1717: BL-Sloane 4045, ff 53 and 64.

${ }^{46}$ Probably McDonnell or McDonald.

${ }^{47}$ JP to JS, 25 November 1717, 5 December 1717 and 10 January 1718 (OS): IBB-JS.

\section{REFERENCES}

ALLEN, D. E., 2004 James Petiver (c. 1665-1718), in MATTHEW, H. C. G. and HARRITON, B. (editors), Oxford dictionary of national biography 43: 894-896. Oxford.

ANDREU SUGRANYES, J., 1995 El Camp de Tarragona $i$ el Priorat durant els segles xviii $i$ xix. Les bases demogràfiques, agràries i mercantils de l'expansió setcentista. Barcelona.

BAKER, J., 1714. The Deplorable History of the Catalans, from their first Engaging in the War to the Time of their Reduction, with the Motives, Declarations, and Engagements on which they first took Arms. The Letters, Treaties, etc. relating thereto. The Reasons of their continuing in Arms against King Philip; and the Remonstrances used by the Emperor and Great-Britain in their favour. With an Account of what passed in the late Siege of Barcelona, and their private Engagements to stand by one another. Interspers'd with many original Papers and Matters never before printed. London.

BAUHIN, C., 1620 Prodromos theatri botanici. Frankfurt.

BOLÒS, A. de, 1946 El herbario Salvador. Collectanea botanica 1 (1): 1-8.

BOLÒS, A. de, 1959 Nuevos datos para la historia de la familia Salvador. Real Academia de Farmacia de Barcelona. Discursos de Recepción 3: 7-50.

BUONANNI, F., 1681 Ricreatione dell' occhio e della mente nell' osservation' delle Chiocciole proposta a' curiosi delle opere della natura. Rome.

BUONANNI, F., 1684 Recreatio mentis et oculi in observatione animalium testaceorum curiosis naturae inspectoribus. Rome.

CAMARASA, J. M., 1989 Botànica i botànics dels Països Catalans. Barcelona.

CAMARASA, J. M., 1995 Salvadorianae, II: Les Jussieu et les Salvador. Deux families de naturalistes au début du XVIII $^{\mathrm{e}}$ siècle, pp. 69-102 in LAISSUS, Y. (editor), Les naturalistes français en Amérique du Sud, XVI $-X I X^{e}$ siècles. Paris.

CAMARASA, J. M., 2000 Salvadorianae III. A pre-Linnaeus description of Silene niceensis All., credited to Jaume Salvador i Pedrol, in the 1686 edition of Botanicum Monspeliense by Pèire Magnol. Collectanea botanica 25 (2): 245-253.

CAMARASA, J. M., 2004 De col-lecció privada a museu públic. El Gabinet Salvador de l'Institut botànic de Barcelona. Afers 49: 721-727.

CAMARASA, J. M., 2011 Botigues i rebotigues d'apotecaris, pp. 115-149 in GARCIA ESPUCHE, A., ZARZOSO, A., CAMARASA, J. M., MARTÍNEZ VIDAL, À., PARDO TOMÀS, J., HUGUET TERMES, T., CASES IBÁÑEZ, A. and BELTRAN DE HEREDIA BERCERO, J. (editors), Medicina i farmàcia. Barcelona 1700. Barcelona.

CAMARASA, J. M. and IBÁÑEZ, N., 2007 Joan Salvador and James Petiver: a scientific correspondence (17061714) in time of war. Archives of natural history 34: 140-173. 
CLUSIUS, C., 1576 Rariorum aliquot stirpium per Hispanias observatarum historia. Anvers.

DALECHAMPS, J., 1586-87 Historia generalis plantarum. Lyon. 2 volumes.

DALTON, C., 1912 George I's army 1714-1727. London.

DANDY, J. E., 1958 The Sloane Herbarium. London.

DESMOND, R., 1977 Dictionary of British and Irish botanists and horticulturists, including plant collectors and botanical artists. Third edition. London.

FEUILLÉE, L., 1714-1726 Journal des observations phyiques, mathematiques et botaniques faites par ordre du Roy sur les côtes orientales de l'Amerique meridionale et dans les Indes occidentales. Paris. 3 volumes.

FONTANA, J., 2004 La guerra de Successió: els motius de Catalunya. Revista de Dret Històric Català 3: 11-23.

GRISLEY, G., 1661 Viridarium lusitanicum in quo arborum, fruticum et herbarum diferentiae onomasti insertae, quas in ager ulyssiponensis ultra citraque Tagum ad trigesimum usque lapidem profert. Lisbon.

HERNÁNDEZ, F., 1648 Nova plantarum, animalium et mineralium mexicanorum historia ... . Rome.

JUSSIEU, A. de, 1714 Icones plantarum per Galliam, Hispaniam et Italiam observatae, ad vivum exhibitarum. Paris.

LÓPEZ PIÑERO, J. M., 1979 Ciencia y técnica en la sociedad española de los siglos XVI y XVII. Barcelona.

MARTÍ-ESCAYOL, M. A., 2001 Catalunya dins la xarxa científica de la il-lustració. John Polus Lecaan: medicina i botànica a Barcelona durant la Guerra de Successio. Manuscrits 19: 175-194.

MATA, M., 1994 Menorca británica. Tomo I. La reina Ana y Jorge I. 1712-1727. Mahon.

MICO, F., 1576 Alivio de sedientos. Barcelona.

NISSOLE, G., 1717 Dissertation botànique sur l'origine et la nature du kermes. Histoire de l'Academie Royale des Sciences [1714]: 434-442.

PETIVER, J., 1713 Aquatilium animalium Amboinae \&c. icones et nomina. London.

PETIVER, J., 1715a Fuci, spongiae, pennae et musci maris Mediterranei. London.

PETIVER, J., 1715b Musci marini. Corallinae \&c Maris Mediterranei. London.

PETIVER, J., 1715c Plantarum Italiae marinarum et graminum icones et nomina. Tabula III. Gramina italiana. London.

PETIVER, J., 1715d Plantarum Italiae marinarum et graminum icones et nomina. Tabula IV. Gramina italiana. London.

PETIVER, J., 1716a Petiveriana seu naturae collectanea. I. London.

PETIVER, J., 1716b Petiveriana seu naturae collectanea. II. London.

PETIVER, J., 1716c Concordia graminum et muscorum. London.

PETIVER, J., 1717 Petiveriana seu naturae collectanea. III. London.

PLUMIER, C., 1705 Traité des Fougères de l'Amerique. Paris.

PORTA I BERGUEDÀ, J., 1995 La victòria catalana de 1705. Barcelona.

POURRET, P. A., 1796 Noticia historica de la familia Salvador de Barcelona. Barcelona.

POURRET, P. A. and COLMEIRO, M., 1844 Noticia histórica de la familia Salvador de Barcelona. Nueva edición corregida y adicionada. Barcelona.

RAY, J., 1673 Observations topographical, moral, and physiological made in a journey through part of the LowCountries, Germany, Italy, and France ...; whereunto is added a brief account of Francis Willughby, Esq., His voyage through a great part of Spain. London.

RAY, J., 1690 Synopsis methodica stirpium britannicarum. London.

RAY, J., 1693-1704 Historia plantarum generalis. London. 3 volumes.

RAY, J., 1705 Methodus insectorum seu insecta in methodum aliqualem digesta. London.

RAY, J., 1713 Synopsis methodica avium et piscium. London.

SALVADOR I RIERA, J., 1972 Viatge d'Espanya i Portugal (1716-17). (Edited by R. Folch i Guillén.) Barcelona.

SLOANE, H., 1696 Catalogus plantarum quae in insula Jamaica sponte proveniunt ... . London.

SWIFT, J., 2009 Journal to Stella, with preface, introduction and notes by George A. Aitken. Adelaide. 
TOURNEFORT, J. P. de, 1689 Schola botanica, sive, Catalogus plantarum quas ab aliquot annis in Horto Regio Parisiensi studiosis indigitavit. Amsterdam.

TOURNEFORT, J. P. de, 1700 Institutiones rei herbariae. Paris.

VOLTES, P., 1967 L'arxiduc Carles d'Àustria, rei dels catalans. Barcelona.

Received 5 July 2011. Accepted 25 August 2011.

APPENDIX: The original texts of Joan Salvador's letters and other documents written in French

1. JS to JP, 8 September 1715 (NS): BL-Sloane 4065, f. 230.

\begin{abstract}
Monsieur avertir. mon coeur

Monsieur

Votre tres humble et tres obeissant serviteur et amy

Barcelone ce 87 bre 1715

Jean Salvador Apotiquaire de Barcelone
\end{abstract}

Après plusieurs fois que j'avez souhaitte vous faire tenir l'argent que vous aviez debourse pour moi, je viens de prendre cette lettre de change que Mr Crowe m'a donné pour Mr son frere Mitford Crowe elle est veue, selon votre compte des livres que vous m'avez envoié monte a $23 £$. $4 \mathrm{sch}$. 5: je vous demande pardon du retardement: De Mr. Mitford Crowe vous donneront des nouvelles chez Mr Mestins qui loge vis a vis de la bourse Royal en Cornhill, j'espere vous sera payée des que vous l'aurez presentée, de quoi je vous prie de m'en

J'ai deja une boitte preste a vous envoier par la premiere occasion, Mr Crowe m'a dit qu'au mois d'octobre partiron quelques vaisseaux et il aura soins de l'embarquer, je l'adresse a Mr le docteur Lecaan, il y a quelques graines, Plantes, Pierres, \&c. j'attends avec une grande impatience quelque chose de vous, surtout de Coquilles, Pierres et Mineraux d'Angleterre, s'il y a quelque livre noveau, je vous prie de me l'envoier et je reste de tout

\title{
2. JS to JP and HS, 10 September 1715 (NS): BL-Sloane 4065, f. 231, and 4044, f. 94.
}

Barcelone ce $107 \mathrm{bre} 1715$

Monsieur

J'adresse pour vous a Monsieur le Docteur Lecaan une petite boitte avec quelques coquilles et pierres, un petit paquet avec plantes seches et un autre avec quelques semences. Je n'ai point pu faire les herborisades que je souhaittés mais en attendant je vous prie de vouloir bien accepter ce peu de choses. J'espere que vous aurez la bonté de m'envoier quelques unes de vos [raretés] et de croire que je suis veritablement

Monsieur

Votre tres humble et tres obbeis-

sant serviteur

Jean Salvador Apotq. de Barcelone

\section{JS to JP 4 January 1716 (NS): BL-Sloane 4065, ff 236-237.}

Monsieur et cher ami

Je suis bien aise que vous aiez receu la lettre de change que Mr Crowe m'avait donné contre Mr son frere: mais celle de six livres Sterlines, Mr Crowe et Speeman et Schallet m'on dit etoit contre Mr Schaller et Compagnie, car depuis le mois de 7bre 1708, je leurs ai donné l'argent et je vous ai envoie la lettre de change. [Ainsi]. je vous prie de voir Mr Schallet de la part de Messieurs Crowe et Compagnie, pour vous payer la ditte somme, et en cas qu'ils vous refusassent de payer, ayant donné avis a Mr Crowe, me donneront une autre lettre. J'ai receu la votre de 25 Abril par la voye de Madrid, dans la quelle j'ai veu les deux tables et un Catalogue des Plantes, celles que je trouverai ici je vous les envoierai, comme aussi les Gramina \&c. qui sont figures dans votre derniere: je serai bien aise de recevoir par la premiere occasion les livres et Catalogues que vous me mentionez 
dans la votre, et si vous voulez les [pourrez] adresser a Mrs Schallet et Crowe, ici a Barcelone, et donner le paquet a Mr son frere ou a Mr Schallet a Londres, et je vous serai bien obligé de y mettre les Coquilles rares, celles d'Angleterre, et aussi les mineraux et plantes. Si vous voulez aussi m'envoier les livres pour Mr Burlet et Mr Riqueur, je tacherai de les envoier a Madrid car nous avons ici toujours commodité de quelques amis, qui y vont. Je viens [illeg.] a votre adresse une quaisse avec le vaisseau nomme Henry, et le Capitaine Henry Land, qui va directement a Londres, et que Mr Crowe m'a fait embarquer, et recomandé au Capitaine: dans cette quaisse vous y trouverez une boitte pour vous avec un paquet aussi de plantes et de semences; une autre pour le docteur Sloan, que je vous prie de lui faire aporter; et une autre aussi pour Mr Rand, contenant a peu près la mesme chose, j'espere aussi vous lui ferez [bailler]. J'ai voulu vous l'adresser pour recevoir le votre fidelement. Je vous serai bien obligé d'abord que vous aurez imprim votre herbarium Britannicum de me l'envoier, comme aussi les autres livres noveaux et de tout je vous fournirai la depence. Si vous me faissez l'honneur de me proposer a votre Illustre et Celebre Societé, je ne manquerai pas de leur faire part de toutes mes decouvertes, et le plutost que je pourai vous envoier mon Botanomasticon Catalonicum, qu'auparavant je dois faire un voyage par quelques endroits de Catalogne, qu'a cause de la guerre je n'ai pu faire; et apres je vous ferai part aussi des Catalogues des Animaux et Mineraux, \&c. je ne doutte que pour votre moien vous y reussirez: je ne manquerai pas souvent de vous ecrire, comme aussi je l'espere de vous, et parce que les lettres ne se perdent, vous pourrez y mettre dessus mon adresse, celle d'en bas, qui est un de mes amis, qui loge chez le courrier major: Je vous prie aussi de donner l'incluse a Mr Squire, Apotiquaire, qui vient de son fils et je vous prie par vos lettres de me donner de ses novelles car il y a long temps qui n'a point ecrit a son fils, je reste avec toutte l'estime et attachement

Monsieur

Votre très humble et tres

obeisant serviteur et ami

Barcelone ce 4

Janvier 1716

Jean Salvador Apote

Barcelone

Monsieur

Monsieur l'Abb Augustin Rovira

chez le courrier major

a Barcelone

\section{JS to JP 6 April 1716 (NS): BL-Sloane 4065, f. 244.}

\section{[Monsie]ur}

[illeg.] long temps que je n'ai point reçu de vos nouvelles, ni la reponse a ma derniere, je vous serai bien oblig de repondre et aussi m'avertir si vous receu ce que j'ai eu l'honneur de vous envoier dernierement. Mr Napier, m'ecrivit d'alger qu'etoit de depart pour Londres, et de lui ecrire la, adressant la lettre a vous, je vous serai oblige de vouloir lui donner l'incluse et aussi vouloir m'envoier quelque chose de curieux, vous obligerez infiniment a celui qui est veritablement

Monsieur

Votre tres humble et tres obeissant

Serviteur et ami

Barcelona ce

6 avril 1716

Jean Salvador

\section{JS to JP 2 August 1716 (NS): BL-Sloane 4065, f. 256.}

\footnotetext{
Monsieur

Il a longtemps Mr que je n'ai point receu de vos nouvelles, j'ai eu l'honneur de vous ecrire quelques fois sans avoir eu reponce je ne scai si les lettres se perdent en chemin: j'ai sceu que vous avez fait deja imprimer le Collectanea Petiveriana, je vous serai tres obligé de vouloir bien me l'envoier l'adressant a Mr Schallet [sic] ou a quelque autre persone de nos amis; j'arrivé avant hier du Monts Pyrenées chargé de belles plantes, je vous en ferai part de touttes, je vous prie de vouloir vous souvenir de moi en m'envoiant quelque chose pour mon Cabinet et vous obligerez veritablement
} 


\author{
Monsieur \\ Votre tres humble et tres obeis- \\ sant serviteur et amy \\ Barcelone ce 2 \\ Aoust 1716 \\ Jean Salvador
}

\title{
6. JS to JP 9 August 1716 (NS): BL-Sloane 4065, f. 257.
}

Barcelone ce 9 Aoust 1716

Monsieur et cher ami

Je viens de recevoir hier votre lettre dattée 29 May, je suis fort ravi vous aiez receu la boitte avec ce que j'avois l'honneur de vous envoier: je vous suis tres obligé de me procurer une bonne collection de differentes choses que vous me dites m'envoierez par le premier navire qui partirai, je scai bien qu'il y en a plusieurs a Londres qui chargent du Bled pour porter en droitture ici a Barcelone, ils partiront bien tost et viendront remis ou a Mrs Schaller et Crowe ou a Mr Gregoire Freind Marchand Anglois ou a Mrs Fontaner et Joffre, je vous serai tres obligé de voloir bien m'envoier par cette voye tout ce que vous aurez de curieux et si vous y voulez joindre un echantillon de ce que vous nommez dans votres Collectanea marque avec le numero; vous m'obligerez aussi de m'envoier de touttes les especes de Coquilles terrestres et maritimes d'Angleterre, les Mineraux, et surtout de la miniere d'Etain, Petrifications, Drogues et Mineraux et ses parties, [Oysseaux] \&c. Je vous envoierai une bonne collection, et un Catalogue des plantes des Monts Pyrénées des quels il y a cinc ou six jours que je suis arrivé d'herboriser et chargé des belles plantes et de tout ce que je trouverai vous ferai part. J'espere au commencemant de 7 bre faire un voyage en Espagne et Portugal et de tout ce que ramasserai vous ferai part. J'ai une bonne correspondence avec Mr Nissolle car ne passe pas courier sans m'ecrire mais jamais m'a parlé de son Botanicon Avenionense et non plus de autres de Provence de Mr [Freuque]. Je vous remercie de votre souvenir quand vous aurez l'occasion d'estre de la Societé Royale: Si vous avez imprimé quelque autre chose, et s'il y a quelque livre noveau de Physique et l'histoire de [illeg.] vous m'obligerez de me l'envoier et de croire que je suis veritablement

Votre tres humble serviteur

et les autres traittes de

Mr Scheuchzer

Jean Salvador

\section{JS to JP, 23 February 1716 (NS): BL-Sloane 4065, f. 277.}

\author{
Monsieur \\ je vous ecrirai, et croyez moi toujours \\ Monsieur \\ Votre tres humble et tres \\ obeissant serviteur et amy \\ Lisboa ce $23 \mathrm{fe}$ - \\ vrier 1717 \\ Jean Salvador
}

Apres avoir herborisé une bone partie d'Espagne avons commencé a herboriser Portugal, ou nous avons trouvé beaucoup des plantes et nous allons en continuant jusque en Galice, Castille, \&c. pour nous rendre aprés a Barcelone, je vous ferai part de touttes les plantes d'Espagne et Portugal comme aussi des Pierres, semences et autres, ayant arrivé a Bar ${ }^{\mathrm{a}}$ tous les envois que nous avons fait, j'espere a mon retour trouver quelque chose que vous m'aurez fait l'honneur de m'envoier. Si nous [aurions] pu herboriser le Mont Gibraltar nous aurions trouvez quelque chose de poli, mais le Gouverneur est si jaleux des fortifications, qui ne voulut permettre d'y monter, disant qu' on decouvre les fortifications, enfin nous partimes bien chagrinez. a mon retour de Barcelone

\section{JS to HS, 14 October 1717 (NS): BL-Sloane 4045, f. 53.}

\section{Monsieur}

Je profitte l'occasion d'un Vaisseau Anglois, qui va directement a Londres pour vous faire part des quelques Plantes que nous avons aporté de notre voyage d'Espagne et Portugal, j'espere, vous y en trouverez quelques 
unes qui vous fairont plaisir, je tacherait de vous faire part de quelque autre chose quand j'aurois tout mis en ordre et croyez moi toujours

Monsieur

Votre tres humble

et tres obeissant serviteur

Barcelone ce 14 8bre 1717

Jean Salvador Apotr

\title{
9. JS to HS, 13 November 1717 (NS): BL-Sloane 4045, f. 64.
}

\author{
Monsieur \\ veritablement \\ Monsieur \\ Votre tres humble et tres obeissant \\ serviteur \\ Barcelone ce \\ 139 bre 1717 \\ Jean Salvador Apot.
}

Il a trois ou quatre semmaines que j'ai embarque sur le vaisseau nommé La Galere Florence, Capitaine michel Magdonel un paquet dans le quel vous trouverez quelques plantes seches que nous avons apporté de notre voyage d'Espagne et Portugal, j'espere vous en trouverez quelques unes qui vous feront plaisir. je l'ai adressé Monsieur [Wyatt] Marchand de Londres. quand le vaisseau sera arrivé chez lui vous pourrez envoier chez lui, qui vous le rendra. je vous serai obligé si vous vouliez me faire part de quelque chose et croyez moi toujours 